\title{
Nutritional Evaluation of Leaf Protein Concentrates Coagulated by Anaerobic Fermentation of Plant Juice in Rats
}

\author{
Mitsuaki Ohshima* and Hiroshi Ueda \\ Faculty of Agriculture, Kagawa University, Miki-cho, \\ Kagawa-ken 761-07
}

(Received October 31, 1985)

\begin{abstract}
The nutritive value of leaf protein concentrates (LPCs) coagulated by 7 days anaerobic fermentation of plant juice was compared with that of LPCs coagulated by heating the juice to $70^{\circ} \mathrm{C}$ using lucerne and Italian ryegrass as material crops. The LPCs were oven-dried at $70^{\circ} \mathrm{C}$ and fed to rats at $10 \%$ protein level with supplementary amino acid (s). Freeze-dried LPC was also prepared from ryegrass and effect of drying methods on the nutritive value was also studied. Both fermentation and oven-drying were responsible for the reduction of apparent digestibility of crude protein and consequently the lowest digestibility was observed in the fermentation-coagulated and oven-dried LPC. Even if being freeze-dried, the fermentation-coagulated LPC was lower in the digestibility than the heat-coagulated and oven-dried LPC. Supplementation of methionine was effective in improving the nutritive value of every LPC. Supplementation of lysine in combination with methionine further improved the nutritive value of LPCs except for the heat-coagulated and freeze-dried LPC which contained enough lysine. The available lysine content of the heat-coagulated LPCs was reduced during the oven-drying process, while that of the fermentation-coagulated LPCs was reduced during the fermentation process. All the differences in the nutritive value among the ryegrass LPCs were derived from the different digestibilities. The fermentation-coagulated lucerne LPC contained some detrimental substances to enhance the urinary nitrogen excretion of rats.
\end{abstract}

Jpn. J. Zootech. Sci., 57 (5): 416-421, 1986

Key words: LPC, fermentation, nutritive value

In the preceding paper ${ }^{1)}$, it was reported that leaf protein concentrates (LPCs) coagulated by subjecting plant juice to anaerobic fermentation for 7 days contained less lysine and several other amino acids compared with heat-coagulated LPCs. A similar result was also reported by AmEenuddin et al. ${ }^{2)}$ They further reported that lysine was the limiting amino acid for better feed efficiency in chick diets containing $40 \%$ fermentation-coagulated LPC supplemented with methionine but not with $40 \%$ heat-coagulated LPC containing additional methionine, when both the LPCs were spray-dried. Ohshima and Matsuhana ${ }^{3)}$ also reported that the true digestibily of leaf protein was reduced during anaerobic fermentation of plant juice.

The present study was made to show the difference between heat-coagulated and fermentation-coagulated LPCs more precisely than mentioned above through nitrogen balance test using seven kinds of LPCs prepared in the preceding study ${ }^{1}$.

* Present address: University Farm, Faculty of Agriculture, Nagoya University, Togo-cho, Aichi-ken 470-01 


\section{Materials and Methods}

The detail descriptions on the LPCs used in this study are available in the preceding paper ${ }^{1}$. The LPCs from the three cuts of lucerne were mixed at every precipitation treatment. The treatments were; heating to $70^{\circ} \mathrm{C}$ (L-heat-LPC); heating to $70^{\circ} \mathrm{C}$ after adjusting to $\mathrm{pH} 8$ with $\mathrm{NaOH}$ (L-alkali-heat-LPC); and anaerobical fermentation for 7 days (L-fer-LPC). All the lucerne LPCs were dried with a draft oven at $70^{\circ} \mathrm{C}$ for 24 hours. From Italian ryegrass, a LPC coagulated by heating after adjusting to $\mathrm{pH} 4$ with $\mathrm{HCl}$ (R-acid-heat-LPC) and that coagulated by the fermentation (R-fer-LPC) were prepared. The ryegrass LPCs prepared in April, May and June were oven-dried and mixed at each treatment. Those obtained in December were freeze-dried.

Rat trials were made using diets containing $10 \%$ crude protein provided from one of the LPCs and supplementary amino acid(s). The procedure was similar to that described in an earlier publication ${ }^{4}$ except for the addition of glutamic acid being made to adjust the protein content of the diets.

\section{Results and Discussion}

Three experiments have been carried out on lucerne LPCs and the results are shown in Table 1. In the first experiment, the nutritive values of lucerne LPCs coa-

Table 1. Nutritive value of oven-dried lucerne LPCs ${ }^{1}$

\begin{tabular}{|c|c|c|c|c|c|}
\hline \multirow{2}{*}{$\begin{array}{l}\text { Coagulation methods of } \\
\text { LPCs and supplementary } \\
\text { amino acids }\end{array}$} & \multirow{2}{*}{$\begin{array}{l}\text { Body } \\
\text { weight } \\
\text { gain }\end{array}$} & \multirow{2}{*}{$\begin{array}{l}\text { Feed } \\
\text { intake }\end{array}$} & \multirow{2}{*}{$\begin{array}{l}\text { Apparent } \\
\text { digestibility of } \\
\text { crude protein }\end{array}$} & \multirow{2}{*}{$\begin{array}{l}\text { Nitrogen } \\
\text { retention }\end{array}$} & \multirow{2}{*}{$\frac{\text { Urinary } N}{\text { Digested } N}$} \\
\hline & & & & & \\
\hline Experiment 1 & $\mathrm{~g} / 10$ days & $\mathrm{g} / 10$ days & $\%$ & $\%$ & $\%$ \\
\hline Direct heat + Glu & $20.1^{b}$ & $65.4^{\mathrm{a}}$ & $78.3^{b}$ & $46.3^{\circ}$ & $40.1^{\mathrm{bc}}$ \\
\hline Direct heat + Met & $24.3^{b}$ & $70.0^{a}$ & $76.8^{b}$ & $55.4^{d}$ & $28.9^{a}$ \\
\hline Alkali-heat + Glu & $16.2^{\mathrm{ab}}$ & $64.0^{2}$ & $77.3^{\mathrm{b}}$ & $44.6^{\mathrm{bc}}$ & $42.4^{\mathrm{b}}$ \\
\hline Alkali-heat + Met & $24.1^{\mathrm{b}}$ & $66.2^{a}$ & $77.1^{b}$ & $55.6^{d}$ & $28.0^{\mathrm{a}}$ \\
\hline Fermentation + Glu & $9.5^{2}$ & $55.5^{2}$ & $63.6^{2}$ & $27.2^{2}$ & $56.5^{d}$ \\
\hline Fermentation + Met & 18. $7^{b}$ & $62.1^{2}$ & $65.1^{3}$ & $41.1^{b}$ & $35.7^{b}$ \\
\hline Pooled standard error & 1.89 & 3.42 & 0.56 & 0.93 & 1.34 \\
\hline \multicolumn{6}{|l|}{ Experiment 2} \\
\hline Direct heat + Glu + Met & $22.7^{b}$ & $67.7^{x}$ & $78.5^{\mathrm{b}}$ & $54.6^{c}$ & $30.8^{\mathrm{b}}$ \\
\hline Direct heat + Met + Lys & $25.9^{b c}$ & $69.5^{a}$ & $80.5^{b}$ & $65.1^{d}$ & $20.0^{a}$ \\
\hline Alkali-heat + Glu + Met & $23.5^{b c}$ & $67.7^{2}$ & $79.7^{b}$ & $53.9^{\circ}$ & $32.5^{b c}$ \\
\hline Alkali-heat + Met + Lys & $27.8^{c}$ & $67.3^{\mathrm{a}}$ & $80.9^{b}$ & $63.2^{\mathrm{d}}$ & $20.8^{\mathrm{a}}$ \\
\hline Fermentation + Glu + Met & $15.5^{\mathrm{a}}$ & $60.2^{a}$ & $65.8^{a}$ & $40.1^{\text {a }}$ & $40.6^{d}$ \\
\hline Fermentation + Met + Lys & $16.4^{\mathrm{a}}$ & $65.2^{a}$ & $66.2^{3}$ & $44.4^{\mathrm{b}}$ & $33.3^{c}$ \\
\hline Pooled standard error & 1.08 & 2.11 & 0.86 & 0.34 & 0.46 \\
\hline \multicolumn{6}{|l|}{ Experiment 3} \\
\hline $\begin{array}{l}\text { Fermentation } \\
\quad+\text { Glu }+ \text { Met }+ \text { Lys }\end{array}$ & $15.9^{\mathrm{a}}$ & $57.3^{3}$ & $67.1^{2}$ & $45.7^{3}$ & $32.0^{4}$ \\
\hline $\begin{array}{l}\text { Fermentation } \\
\quad+\text { Met + Lys }+ \text { Thr }\end{array}$ & $17.7^{2}$ & $58.6^{3}$ & $67.7^{3}$ & $46.9^{2}$ & $30.9^{2}$ \\
\hline
\end{tabular}

1. Means of 4 rats. Figures with different superscript letters were significantly different at $5 \%$ level. Each amino acid was added $0.4 \%$ of the diets at the expense of cornstarch. 
gulated by the three different ways were compared as well as the supplementary effect of methionine on them. In the second and the third experiments, the effect of methionine and lysine supplementation and that of methionine, lysine and threonine supplementation, respectively, on the nutritive value of LPCs were studied.

L-heat-LPC and L-alkali-heat-LPC were not different in the nutritive value and similarly improved by being supplemented with methionine and lysine. The combination of methionine and lysine showed better nutritive value than methionine alone. The body weight gain (BWG), the apparent digestibility of crude protein (AD) and the nitrogen retention (NR) were lower and the rate of urinary nitrogen to digested nitrogen (UN/DN) was higher in rats fed on L-fer-LPC than in those fed on Lalkali-heat-LPC. These fact suggests that the lower performance of rats fed on $\mathrm{L}_{-}$ fer-LPC was attributable to both the lower absorption rate of dietary amino acids and the lower assimilation rate of absorbed amino acids. The UN/DN was reduced by methionine supplementation and further reduced by being supplemented both methionine and lysine to the lucerne LPCs. However, the rats fed on L-fer-LPC excreted more UN than those on the heat-coagulated LPCs at each amino acid treatment. It was supposed that the above difference in UN/DN between fermentationand heat-coagulated lucerne LPCs might be derived from the different contents of the limiting amino acids. In an earlier publication ${ }^{5}$, it was reported that the first, second and third limiting amino acids of heat-coagulated, precipitated by settling and ovendried ladino clover LPC were methionine, lysine and threonine, respectively, and in the present study, much reduction of threonine was observed during the fermentation as shown in the preceding paper ${ }^{1)}$. Therefore, supplementation of threonine to $\mathrm{L}-$ fer-LPC containing additional methionine and lysine was made, but it was not effective in improving the nutritive value suggesting the presence of some detrimental factors enhancing the UN excretion in L-fer-LPC.

The nutritive value of oven-dried R-acid-heat- and R-fer-LPCs were determined and the results are shown in Table 2. The BWG, AD and NR of rats fed on R-

Table 2. Nutritive value of oven-dried ltalian ryegrass $\mathrm{LPCs}^{1}$

\begin{tabular}{|c|c|c|c|c|c|}
\hline \multirow{2}{*}{$\begin{array}{l}\text { Coagulation methods of } \\
\text { LPCs and supplementary } \\
\text { amino acids }\end{array}$} & \multirow{2}{*}{$\begin{array}{l}\text { Body } \\
\text { weight } \\
\text { gain }\end{array}$} & \multirow{2}{*}{$\begin{array}{l}\text { Feed } \\
\text { intake }\end{array}$} & \multirow{2}{*}{$\begin{array}{l}\text { Apparent } \\
\text { digestibility of } \\
\text { crude protein }\end{array}$} & \multirow{2}{*}{$\begin{array}{l}\text { Nitrogen } \\
\text { retention }\end{array}$} & \multirow{2}{*}{$\frac{\text { Urinary } N}{\text { Digested N }}$} \\
\hline & & & & & \\
\hline & $\mathrm{g} / 10$ days & $\mathrm{g} / 10$ days & $\%$ & $\%$ & $\%$ \\
\hline Acid-heat +2 Glu & $23.7^{6 \mathrm{c}}$ & $69.3^{3}$ & $82.2^{b}$ & $49.4^{b}$ & $40.0^{\circ}$ \\
\hline Acid-heat + Glu+Met & $27.2^{\mathrm{ct}}$ & $69.9^{\mathrm{a}}$ & $82.1^{b}$ & $57.4^{\mathrm{d}}$ & $30.1^{b}$ \\
\hline Acid-heat + Met + Lys & $29.8^{d}$ & $70.3^{a}$ & $82.4^{b}$ & $63.5^{\mathrm{e}}$ & $23.0^{2}$ \\
\hline Fermentation +2 Glu & $19.0^{\mathrm{a}}$ & $67.7^{a}$ & $70.1^{a}$ & $41.5^{a}$ & $40.8^{\mathfrak{c}}$ \\
\hline Fermentation + Glu + Met & $21.0^{2 b}$ & $68.8^{2}$ & $69.5^{2}$ & $46.6^{b}$ & $32.9^{\mathrm{b}}$ \\
\hline Fermentation + Met + Lys & $22.5^{\mathrm{ab}}$ & $66.2^{\circ}$ & $69.9^{n}$ & $53.8^{\circ}$ & $23.1^{a}$ \\
\hline Pooled standard error & 0.94 & 1.10 & 0.45 & 0.72 & 0.77 \\
\hline
\end{tabular}

1. Means of 4 rats. Figures with different superscript letters were significantly different at $5 \%$ level. Each amino acid was added $0.4 \%$ of the diets at the expense of cornstarch except for those shown as $2 \mathrm{Glu}$ in which glutamic acid was added $0.8 \%$ of the diets. 
Nutritional Evaluation of Fermentation-Coagulated LPC

Table 3. Nutritive value of oven-dried and freeze-dried ltalian ryegrass $\mathrm{LPCs}^{1}$

\begin{tabular}{|c|c|c|c|c|c|c|c|}
\hline $\begin{array}{l}\text { Coagulation } \\
\text { method }\end{array}$ & $\begin{array}{l}\text { Drying } \\
\text { method }\end{array}$ & $\begin{array}{l}\text { Supplemen- } \\
\text { tary amino } \\
\text { acid }\end{array}$ & $\begin{array}{l}\text { Body } \\
\text { weight } \\
\text { gain }\end{array}$ & $\begin{array}{l}\text { Feed } \\
\text { intake }\end{array}$ & $\begin{array}{l}\text { Apparent } \\
\text { digestibility of } \\
\text { crude protein }\end{array}$ & $\begin{array}{l}\text { Nitrogen } \\
\text { retention }\end{array}$ & $\frac{\text { Urinary } N}{\text { Digested } N}$ \\
\hline \multirow{7}{*}{ Acid-heat } & & & $\begin{array}{c}\mathrm{g} / 10 \\
\text { days }\end{array}$ & $\begin{array}{l}\mathrm{g} / 10 \\
\text { days }\end{array}$ & $\%$ & $\%$ & $\%$ \\
\hline & Oven dry & 2Glu & $20.5^{\mathrm{ab}}$ & $70.4^{7}$ & $80.5^{\mathrm{c}}$ & $47.8^{\mathrm{r}}$ & $42.1^{d}$ \\
\hline & & Glu + Met & $25.2^{\mathrm{cd}}$ & $69.9^{\mathrm{a}}$ & $80.6^{c}$ & $56.0^{\circ}$ & $32.3^{c}$ \\
\hline & & Met + Lys & $28.0^{d e}$ & $71.2^{\mathrm{a}}$ & $81.3^{c}$ & $61.5^{f}$ & $24.6^{\mathrm{ab}}$ \\
\hline & Freeze dry & $2 \mathrm{Glu}$ & $20.6^{\mathrm{ab}}$ & $69.1^{*}$ & $83.3^{d}$ & $48.3^{c}$ & $42.6^{\mathrm{d}}$ \\
\hline & & Glu+Met & $29.9^{\mathrm{e}}$ & $70.6^{2}$ & $83.7^{d}$ & $61.7^{1}$ & $25.5^{\circ}$ \\
\hline & & Met + Lys & $29.7^{\mathrm{e}}$ & $72.4^{\mathrm{a}}$ & $83.0^{d}$ & $60.9^{f}$ & $26.2^{\mathrm{b}}$ \\
\hline \multirow[t]{6}{*}{ Fementation } & Oven dry & $2 \mathrm{Glu}$ & $17.6^{a}$ & $68.8^{2}$ & $68.2^{a}$ & $40.2^{a}$ & $42.8^{d}$ \\
\hline & & $\mathrm{Glu}+\mathrm{Met}$ & $21 \cdot 3^{b}$ & $69.0^{\mathrm{a}}$ & $69.1^{*}$ & $46.0^{b c}$ & $32.9^{c}$ \\
\hline & & Met + Lys & $22.5^{b c}$ & $70.5^{2}$ & $68.3^{a}$ & $52.1^{d}$ & $24.2^{a b}$ \\
\hline & Freeze dry & 2 Glu & $20.9^{a b}$ & $70.1^{a}$ & $76.9^{b}$ & $44.8^{b}$ & $41.8^{d}$ \\
\hline & & Glu + Met & $23.1^{b c}$ & $69.5^{\mathrm{a}}$ & $77.6^{b}$ & $52.5^{d}$ & $32.2^{c}$ \\
\hline & & Met + Lys & $23.6^{b c}$ & $71.7^{2}$ & $76.3^{6}$ & 58. $9^{\mathrm{e} f}$ & $22.8^{\mathrm{a}}$ \\
\hline \multicolumn{3}{|c|}{ Pooled standard error } & 0.69 & 0.79 & 0.38 & 0.63 & 0.47 \\
\hline
\end{tabular}

1. See the footnote of Table 2 .

acid-heat-LPC were superior to those of rats fed on R-fer-LPC, but the UN/DN was not different between them suggesting the differences in BWG and NR could be attributable to the different AD. By supplementing methionine, UN/DN was reduced and by supplementing methionine and lysine, it was further reduced in both R-acidheat- and R-fer-LPCs to similar extents.

Above result was obtained on LPCs dried at $70^{\circ} \mathrm{C}$ with the draft oven. It was reported in an earlier publication" that $\mathrm{AD}$ and the biological availability of lysine of oven-dried LPC were quite low compared with those of freeze-dried LPC which contained enough lysine for rat growth. But it is not clear whether the reductions of $\mathrm{AD}$ and lysine availability of fermentation-coagulated LPC occurred during fermentation process or oven-drying process. To make clear the above question, freeze-dried and oven-dried R-acid-heat- and R-fer-LPCs were prepared from the same juice and determined for their nutritive values in rats. The results are shown in Table 3 . The $A D$ was the lowest in oven-dried R-fer-LPC and followed by freeze-dried R-fer-LPC suggesting both fermentation and oven-drying processes were responsible on the reduction of $\mathrm{AD}$. During the 7 days' fermentation, the more digestible protein might be preferably degraded to lower peptides and amino acids and removed to the supernatant. HANCZAKowSKI ${ }^{\text {() }}$ reported that whole juice of lucerne stored for 48 hours was similar to heat-coagulated LPC and superior to fresh juice in nutritive value of protein for rats, when fed with barley. This result suggests that if whole juice is used as feed, fermentation is useful for keeping it.

As being evident from UN/DN shown in Table 3, the biologically available lysine content of R-acid-heat-LPC was enough for rat growth but was reduced during the fermentation process to the level to be short to meet the requirement of growing rats 
and was not affected by the oven-drying. This result could be supposed from the total lysine content of LPCs shown in the preceding paper ${ }^{11}$. The different processes of the reduction of available lysine content between fermentation-coagulated and heatcoagulated LPCs might be attributable to the different sugar contents of them. Because centrifugally separated wet LPCs contained 65\% moisture derived from plant juice and it is known ${ }^{7)}$ that plant juice is rich in sugar contents and most of the sugars disappear during anaerobic fermentation. Thus the reaction between lysine and sugars during the oven-drying process might occur in the heat-coagulated LPC but not occur in the fermentation-coagulated LPC.

\section{Acknowledgement}

This work was supported by the Grant-in-Aid for Scientific Research from the Ministry of Education, Science and Culture (Grant No. 59360036). The authors are grateful to Mr. M. Kamada, Mr. I. Aкıтоmo and Mr. M. Ito for their help.

\section{References}

1) Onshima, M. and H. Ueda, Jpn. J. Zootech. Sci., 57: 410-415. 1986.

2) Ameenuddin, S., H. R. Bird, M. L. Sunde and R. G. Koegel, Poultry Sci., 62: 1021-1024. 1983.

3) Ohshima, M. and K. Matsuhana, Jpn. J. Zootech. Sci., 39: 462-466. 1968.

4) Oнshima, M., Jpn. J. Zootech. Sci., 56: 267-273. 1985.

5) Ohshima, M. and K. Oovchi, Nutr. Rep. Int., 14: 611-620. 1976.

6) Hanczakowski, P., J. Sci. Fd Agric., 30: 27-30. 1979.

7) Ohshima, M., P. McDonald and T. Acamovic, J. Sci. Fd Agric., 30: 97 106. 1979. 


\title{
発酵凝固法により搾汁液から分離した緑葉蛋白質濃縮物
}

\section{のラットに対する栄養価}

\author{
大島光昭* ・上田博史 \\ 香川大学農学部，香川県三木町 761-07 \\ *名古屋大学農学部附属農場, 要知県東郷町 470-01
}

ルーサンおよびイタリアンライグラスの搾汁液を1週 間嫌気条件下に保つことにより凝集させた緑葉蛋白質濃 䄸物 (LPC) の栄盖価を，同じ搾汁液を值接あるいは $\mathrm{pH}$ 調整後 $70^{\circ} \mathrm{C}$ に加熱して得られた LPCの栄意洒と比较し た. ライグラス LPC の一部を凍結乾燥した活かは, 凝

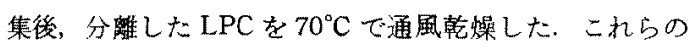
LPC と添加了ミ，酸を蛋白質源とする蛋白質含量 $10 \%$ の飼料を調製しラットに制限給与した。

発酵凝固扎よび通風乾燥のいずれも LPC 蛋白質の消 化率の低下をもたらしたすなおち，蛋白質の消化率は 加熱凝固・凍結漧燥ですっ之も裔く，加熱凝固・通風乾

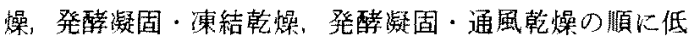
下した。
メチオニンの添加は，すべての LPC において栄盖洒 改善に有効であった，加熱㠜固・凍結教燥 LPCはラッ 卜の生長に十分なリジンを含んでいたが，他の LPC で は不足し，メチォニンと其にりシンを添加することによ り栄息価が改善された。

加熱凝固 LPC に指ける有效りジン含量の低下は通風 嗼燥中に起こったのに対し，発酵㠜固 LPC では発酵中 に低下し，通風乾燥の影響はらけなかった。

通風乾燥した場合ライグラス LPC では，凝固法に よる栄湌価の差は消化率の差のみに帰結されたのに﨎 し、ルーサンでは，発醉凝固 LPC 中に、それのみては 説明できたいマイナス要因が認められた。

日蓄会報，57 (5)：416-421，1986 